\title{
Analysis of High School Students 'Mathematic Critical Thinking Ability with Graded Response Models
}

\author{
Mirunnisa ${ }^{1}$, Zulfa Razi ${ }^{2}$ \\ ${ }^{1,2}$ Universitas Jabal Ghafur, Indonesia \\ mirunnisa0811@gmail.com,zulfarazihb@gmail.com
}

\begin{abstract}
The ability to think critically in mathematics, especially high-level mathematical critical thinking, is needed by students so that students are able to face changing circumstances or challenges that exist in life that is always developing. Graded response models (GRM) are used in order to display the estimated item parameters and students' abilities. This research is a descriptive study with a qualitative approach. Subjects in this study using SMA Simpang Tiga in terms of their mathematical critical thinking skills. Subjects were taken using a mathematical critical thinking ability test, then processed through Microsoft Excel to obtain a Graded Response Models (GRM) graph.Based on data analysis Students can be categorized as highly skilled, in general students can determine the concept of the problem correctly, are able to formulate problems in solving problems, are able to provide reasons and arguments clearly, but students are less able to evaluate problems in solving problems. Students who are categorized as having moderate ability, students can determine the concept of the problem correctly, are able to formulate problems, but students are less clear in providing reasons and arguments clearly, and are less able to evaluate the problems contained in solving problems. Students who are categorized as low, students are able to determine the concept correctly, but students are less able to formulate problems, and students are unable to provide clear reasons.
\end{abstract}

Keywords

mathematical critical thinking ability, Graded Response Models (GRM; problemitems

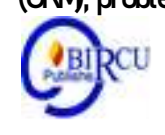

\section{Introduction}

Mathematics is one of the basic sciences for other sciences. According to Mirunnisa (2019), mathematics is a science that deals with ideas (ideas), structures and relationships that are logically arranged so that mathematics is related to abstract concepts. A mathematical truth is developed based on logical reasoning using deductive proof. In the discipline of science, mathematics plays an important role in the development of science and technology, because mathematics learning is not only intended to educate students, but is also intended to produce students who have reasoning power and have good personalities, and hone various other intelligences (Razi, 2019). Therefore mathematics has an important role in improving thinking skills. According to Sabandar (2008),

The ability to think, especially high-order thinking in the form of critical thinking, is very important for students, especially in learning. There are at least five reasons for the importance of critical thinking by students in learning, namely critical thinking, including the 
domain of general thinking skills, important in the modern knowledge economy, increasing language and presentation skills, increasing creativity, and for self-reflection.

Based on experiences and observations in the field, the researcher found several contradictory things which were shown by students with critical thinking skills in Mathematics. For example, it is known that the ability to think critically can be demonstrated by students by questioning where the formula in a theorem comes from. However, there are many cases where students only accept the formula given by the teacher. Accepting the formula in the sense of the word the student has resigned and is sincere that the formula is what it is, does not question where the formula comes from, how it could be like this or that, or why should use this or that operation. Razi and Mirunnisa (2019) said that students as the next generation of the nation to become superior and quality Human Resources (HR).

To find out students' mathematical critical thinking skills, the ability of each student should be measured, namely by using special tests or tests related to certain materials. Students' mathematical critical thinking skills need reasons and sources that are used as references for students to answer the test. The form of essay test (description) can give freedom to students how to reach and explain their own conclusions. Scoring on an essay (essay) test is usually done with a polytomus score, where a graded score of more than two categories is given according to certain criteria.

Noer (2009) explains that in assessing the Graded Response Models (GRM), it is one of the Item Response Theory (IRT) model approaches which aims to display students' mathematical thinking skills, because the form of test used in assessing this model is a description, which requires students to able to think critically, and each item is made based on the level of difficulty from easy to difficult. According to Matteucci and Stacqualursi (2006), Graded Response Models (GRM) are one of the Item Response Theory models for politomus data. The purpose of the Graded Response Models was to present the estimated item parameters and students 'abilities, while the purpose of this study was to analyze and describe students' mathematical critical thinking skills.

Based on the background description above, the formulation of the problem in this study can be generated as follows: How to analyze high school students' mathematical critical thinking skills using Graded Response Models (GRM)? In line with the problem formulation above, the purpose of this study is to analyze and describe students' mathematical critical thinking skills using Graded Response Models (GRM) in SMA.

Based on the description above, the Graded Response Models (GRM) or tiered response model is a scoring system where the difficulty level of each category on the test item is arranged sequentially so that the test taker's answers must be sorted from the low to the highest category.

\section{Research Methods}

The type of research used in this research is qualitative research that produces descriptive data in the form of written or spoken words from people or observable behavior. Whereas qualitative is seen as a complex picture, scrutinizing words, detailed reports of the respondents' views and conducting studies on natural situations. which aims to describe the characteristics of the test being developed, as well as to estimate the ability of the test taker based on the response or answer to the test given. Research subject covering class X SMA Simpang Tiga. 
The data was collected through a written test in the form of a description. The test consists of five (items) which are arranged with reference to indicators of critical thinking skills associated with certain mathematical topics. The projecting of each item consists of 4 graded categories.

The data analysis technique was performed using the Graded Response Model (GRM). GRM is one of the IRT models for polytomous data. GRM is used with the aim of presenting the estimated item parameters and students' abilities (Matteucci and Stacqualursi, 2006). GRM (Samejima, 1969) is an IRT model for polytomic data developed for response items characterized by order of categories. In GRM, each item can be obtained an estimate of one parameter of difference power () and $\mathrm{j}=1$... mi level of difficulty between categories. $\hat{a}_{i} \hat{\beta}_{i j}$

The research instrument was in the form of an essay, prior to use the process of distinguishing power and the difficulty level of the items.

Table 1. Distinguishing Power

\begin{tabular}{|c|c|c|}
\hline Item Questions & Discernment & Criteria \\
\hline 1 & 0.2 & Enough \\
\hline 2 & 0.26 & Enough \\
\hline 3 & 0.32 & Enough \\
\hline 4 & 0.22 & Enough \\
\hline 5 & 0.4 & Good \\
\hline
\end{tabular}

The level of question difficulty is the proportion of test takers who answered correctly, that is, the ratio of the number of test takers who answered correctly to the total number of test takers. The results of the calculation of the difficulty level of the questions can be categorized as follows:

Table 2. Difficulty Level Criteria

\begin{tabular}{|l|l|l|}
\hline Item Questions & Level of Difficulty & Criteria \\
\hline 1 & 0.64 & Enough \\
\hline 2 & 0.47 & Enough \\
\hline 3 & 0.5 & Enough \\
\hline 4 & 0.43 & Enough \\
\hline 5 & 0.32 & Good \\
\hline
\end{tabular}

\section{Result and Discussion}

The results of the critical thinking skills test of 20 students will be shown in the table, which is measured based on the scoring of students' mathematical critical thinking skills. Scoring guidelines are carried out by indicators. The following is the percentage per indicator Table of Percentage of Mathematical Critical Thinking Ability Tests per Indicator:

Table 3. Percentage of Mathematical Critical Thinking Ability Tests per Indicator

\begin{tabular}{|l|l|l|l|}
\hline No. & $\begin{array}{l}\text { Indicators of Mathematical Critical } \\
\text { Thinking Ability }\end{array}$ & Percentage & Category \\
\hline 1 & Determine the concepts used in problem solving. & $71.25 \%$ & Moderate \\
\hline 2 & $\begin{array}{l}\text { Formulate an action (strategy, tactic, or } \\
\text { approach) in solving a problem. }\end{array}$ & $58.75 \%$ & Low \\
\hline
\end{tabular}




\begin{tabular}{|l|l|l|l|}
\hline 3 & $\begin{array}{l}\text { Provide arguments or reasons in answering } \\
\text { and solving problems. }\end{array}$ & Low \\
\hline 4 & $\begin{array}{l}\text { Evaluating the evidence or decisions that } \\
\text { have been taken in solving the problem. }\end{array}$ & $40 \%$ & Low \\
\hline
\end{tabular}

Based on the table above, it can be seen that students' critical thinking skills per indicator can be categorized into 2 categories, namely medium and low. Students' mathematical critical thinking skills in determining concepts in problem solving are included in the medium category, formulating ways of solving problems including in the low category, providing arguments in solving problems including in the low category, and evaluating problem solving included in the low category.

It can be seen that students' mathematical critical thinking skills in solving problems show that students are able to determine concepts in problem solving, but students have not been able to formulate ways to solve problems, students have not been able to provide arguments in solving problems, and students have not able to evaluate problem solving. Everyone must have the students' mathematical critical thinking ability, because by having this ability students can help in thinking rationally in solving or solving a problem. As mentioned by Ennis (1996) there are six elements in critical thinking abbreviated as FRISCO, namely focus, reason, inference, situation, clarity, and overview. so that in overcoming or solving a problem must have the ability to think critically in mathematics. Mathematical critical thinking skills are very important for everyone to have.

\subsection{Data Analysis of Parameter Estimation Results using Graded Response Models (GRM)}

Table 4. Estimating Item Parameters with Graded Response Models (GRM)

\begin{tabular}{|c|c|c|c|c|c|}
\hline \multirow{2}{*}{$\boldsymbol{\theta}$} & \multicolumn{5}{|c|}{ Pjk } \\
\cline { 2 - 6 } & Item 1 & Item 2 & Item 3 & Item 4 & Item 5 \\
\hline-4 & 0.412940064 & 0.277317334 & 0.172932693 & 0.381489169 & 2008.507485 \\
\hline-3.5 & 0.489459861 & 0.345904408 & 0.226989205 & 0.459933751 & 420.3750044 \\
\hline-3 & 0.580159148 & 0.431454673 & 0.297943079 & 0.55450868 & 107.4630621 \\
\hline-2.5 & 0.687665453 & 0.538163523 & 0.391076213 & 0.668530794 & 33.55370134 \\
\hline-2 & 0.815093198 & 0.671263971 & 0.513321554 & 0.805998966 & 12,79618629 \\
\hline-1.5 & 0.966133921 & 0.83728328 & 0.673779199 & 0.971734345 & 5.960457146 \\
\hline-1 & 1.145163224 & 1.044363053 & 0.884393819 & 1.17154944 & 3.391075679 \\
\hline-0.5 & 1.357367525 & 1.302658506 & 1.16084383 & 1.412451971 & 2.35642863 \\
\hline 0 & 1.608894312 & 1.624836476 & 1.523708522 & 1.702890635 & 2 \\
\hline 0.5 & 1.907030234 & 2.026696607 & 2 & 2.053051413 & 2.073311693 \\
\hline 1 & 2.260412188 & 2.527946165 & 2.625174003 & 2.475214801 & 2.625174003 \\
\hline 1.5 & 2.679277532 & 3.153166483 & 3.445769272 & 2.984186501 & 4.059854683 \\
\hline 2 & 3.175760657 & 3.933018434 & 4.522871956 & 3.597816669 & 7.668700545 \\
\hline 2.5 & 3.764244513 & 4.905746046 & 5.936662938 & 4.337625942 & 17.69261252 \\
\hline 3 & 4.461777283 & 6.119051988 & 7.792386604 & 5.229560188 & 49.85641532 \\
\hline 3.5 & 5.288566259 & 7,632436917 & 10.22818537 & 6.304900452 & 171.5967385 \\
\hline 4 & 6.268563243 & 9.520117399 & 13.42538316 & 7.601360015 & 721.3663923 \\
\hline
\end{tabular}


The following is a graph of the results of parameter estimation using Graded Response Models (GRM):

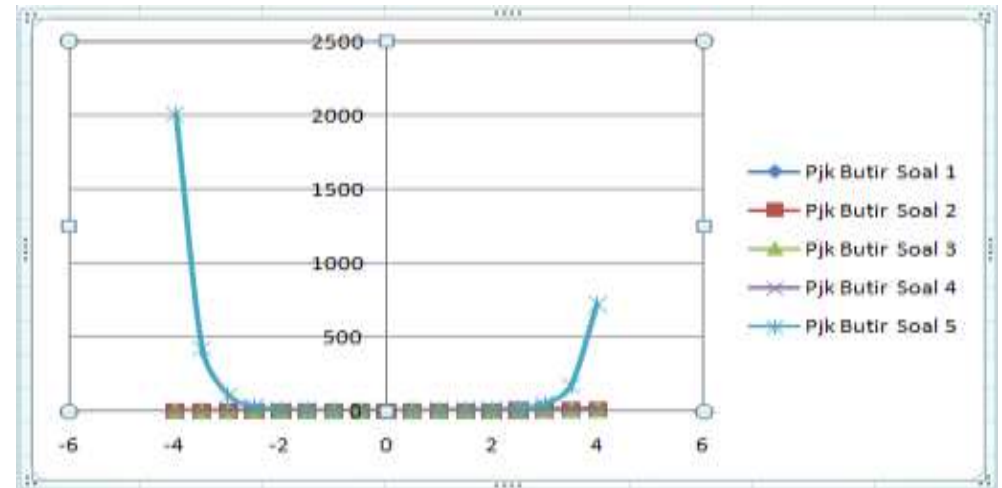

Figure 1. Parameter Estimation Results Using Graded Response Models (GRM)

The ability of students to determine the concept of solving problems in this test resulted in an average percentage of $71.25 \%$. The percentage level of students' ability on this indicator is shown in the following table.

Table 5. Percentage of Level of Indicator Capability 1

\begin{tabular}{|c|c|c|}
\hline $\begin{array}{c}\text { Level of Indicator } \\
\text { Capability }\end{array}$ & $\begin{array}{c}\text { The number } \\
\text { of students }\end{array}$ & $\begin{array}{c}\text { Percentage of Ability Level } \\
\text { Per Indicator }\end{array}$ \\
\hline Low & 4 & $20 \%$ \\
\hline Moderate & 9 & $45 \%$ \\
\hline High & 7 & $35 \%$ \\
\hline
\end{tabular}

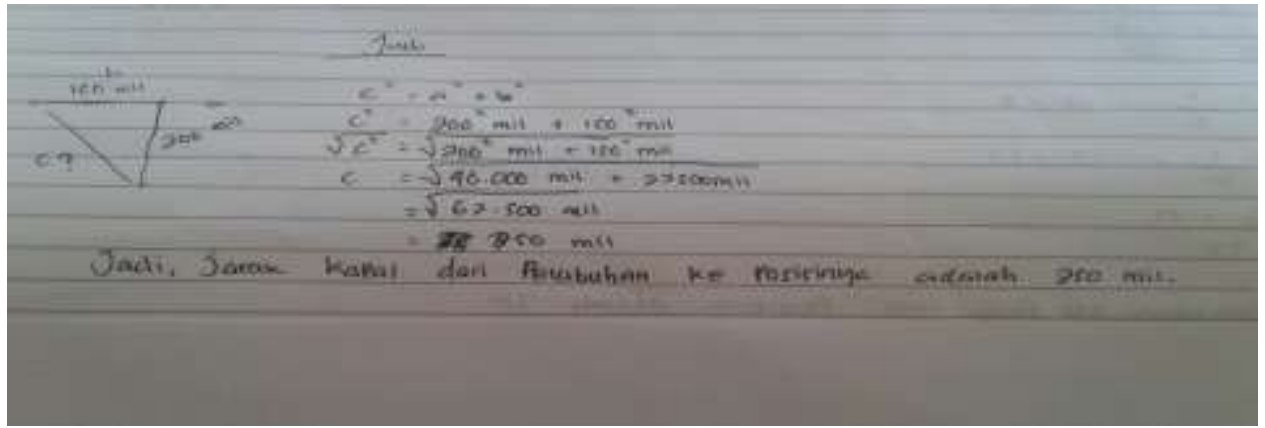

Figure 2. The description of the problem number 1 indicator determines the concepts used in problem solving

$S_{1}$ in this study are students who belong to the category high. Answers from students $S_{1}$ shown in question number 1 which measures mathematical critical thinking skills on indicator 1. Students $S_{1}$ get a score of 4 because the answer is correct and applies the concept in question, namely the Pythagorean theorem, and the correct way to sketch the ship's direction, namely north upward and Bart left direction. Then students are able to draw a line from the starting point to the end point to find the distance of the ship. $S_{1}$ 


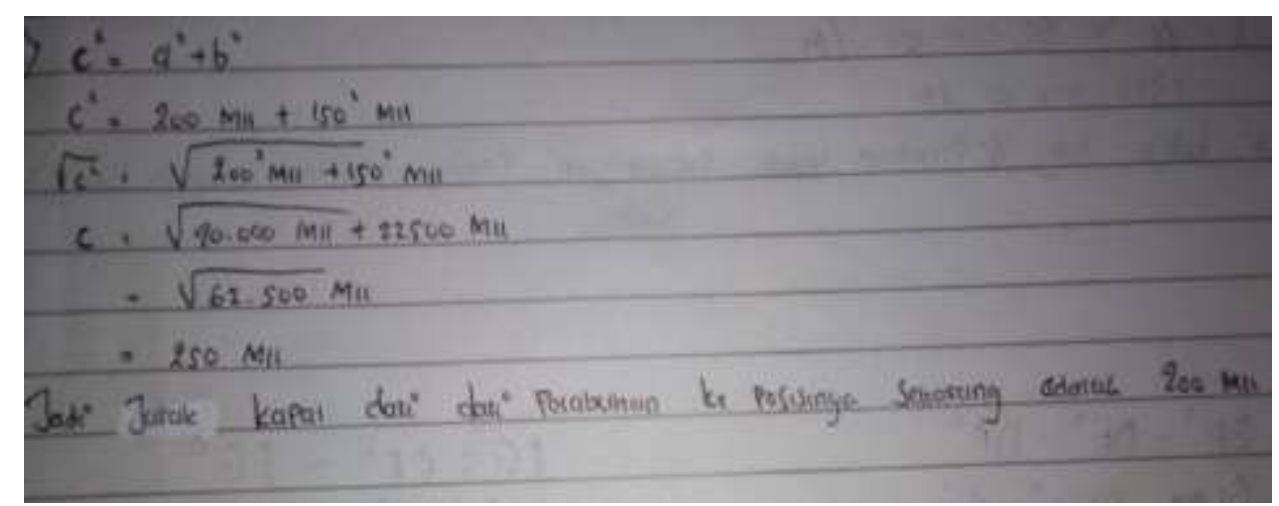

Figure 3. The description of the problem number 1 indicator determines the concepts used in problem solving

$S_{12}$ in this study are students who belong to the category moderate. Answers from students $S_{12}$ shown in question number 1 . In mathematical calculations, the student's answer is correct, but the answer is an error $S_{12}$ does not make a sketch to show the wind direction of a ship and at the time of drawing $S_{12}$ lack of focus, so the results are different. Walaupum $S_{12}$ using the Pythagorean formula and the answer is correct, $S_{12}$ get a score of 2.

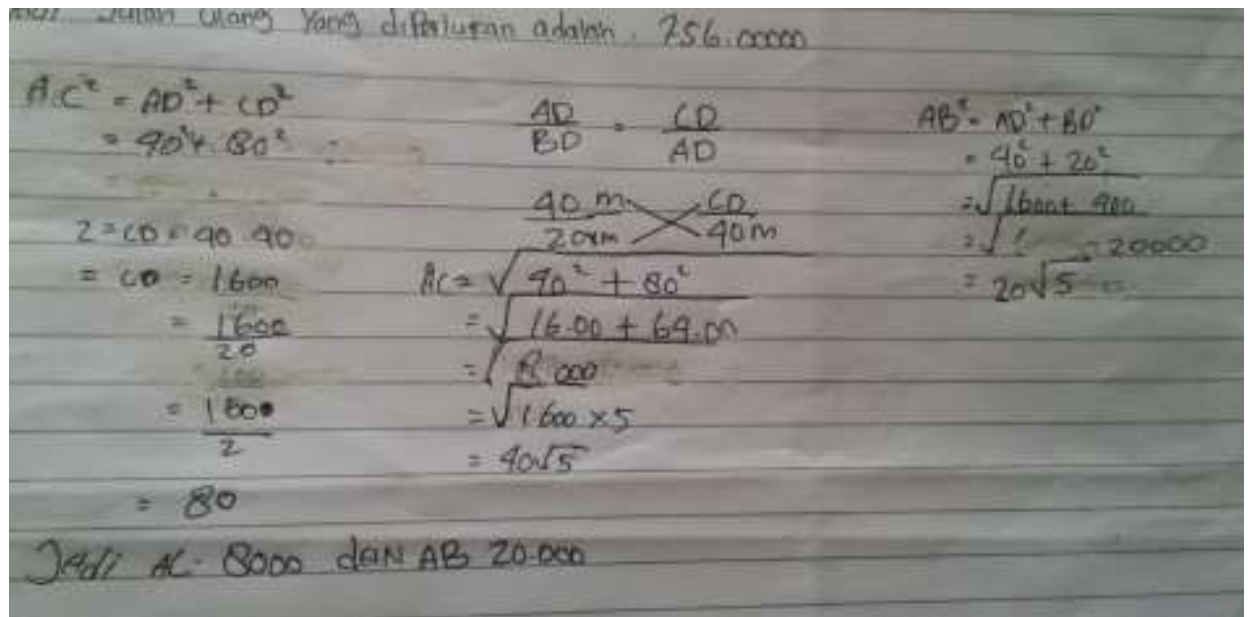

Figure 4. The description of question number 3 indicators determines the concept used in problem solving

$S_{14}$ in this study are students who belong to the category moderate. Answers from students $S_{14}$ shown in question number 3. In mathematical calculations, the student's answer is correct but lacks focus, because $S_{14}$ err at the time of the final results, and to draw conclusions $S_{14}$ less precise. The score is 2 , because it does not describe what is known on the problem, does not focus on answering questions, and draws inaccurate conclusions. $S_{14} S_{14}$

\subsection{Formulating Ways in Problem Solving}

The ability of students to formulate ways to solve problems on this test resulted in an average percentage of $58.75 \%$. The percentage level of students' ability on this indicator is shown in the following table. 
Table 6. Percentage of Ability Level Indicator 2

\begin{tabular}{|l|l|l|}
\hline $\begin{array}{l}\text { Level of Indicator } \\
\text { Capability }\end{array}$ & $\begin{array}{l}\text { The number } \\
\text { of students }\end{array}$ & $\begin{array}{l}\text { Percentage of Ability Level } \\
\text { Per Indicator }\end{array}$ \\
\hline Low & 4 & $20 \%$ \\
\hline Moderate & 4 & $20 \%$ \\
\hline High & 12 & $60 \%$ \\
\hline
\end{tabular}

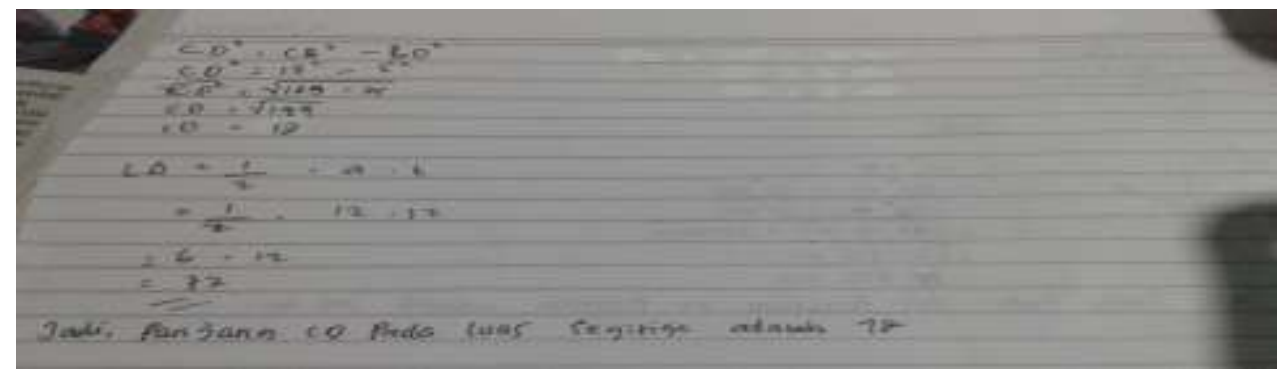

Figure 5. The description of question number 2 indicators formulates an action (strategy, tactic, or approach) in solving the problem.

$S_{2}$ in this study are students who belong to the category high. Janswers from students $S_{2}$ shown in question number 2. In mathematical calculation, answer $S_{2}$ is correct, because it has applied the formula correctly. To get the length of CD, use the phitagorean formula and find the area of a triangle using the area formula of the triangle, and $S_{2} S_{2}$ able to draw conclusions correctly. $S_{2}$ get a score of 3 , because it does not explain what is known in the problems contained in the questions. $S_{2}$

\subsection{Providing Arguments in Problem Solving}

The student's ability to provide arguments in solving problems on this test resulted in an average percentage of $52.4 \%$. The percentage level of students' ability on this indicator is shown in the following table.

Table 7. Percentage of Ability Level Indicators 3

\begin{tabular}{|l|l|l|}
\hline $\begin{array}{c}\text { Level of Indicator } \\
\text { Capability }\end{array}$ & $\begin{array}{c}\text { The number } \\
\text { of students }\end{array}$ & $\begin{array}{c}\text { Percentage of Ability Level } \\
\text { Per Indicator }\end{array}$ \\
\hline Low & 3 & $15 \%$ \\
\hline Moderate & 11 & $55 \%$ \\
\hline High & 6 & $30 \%$ \\
\hline
\end{tabular}

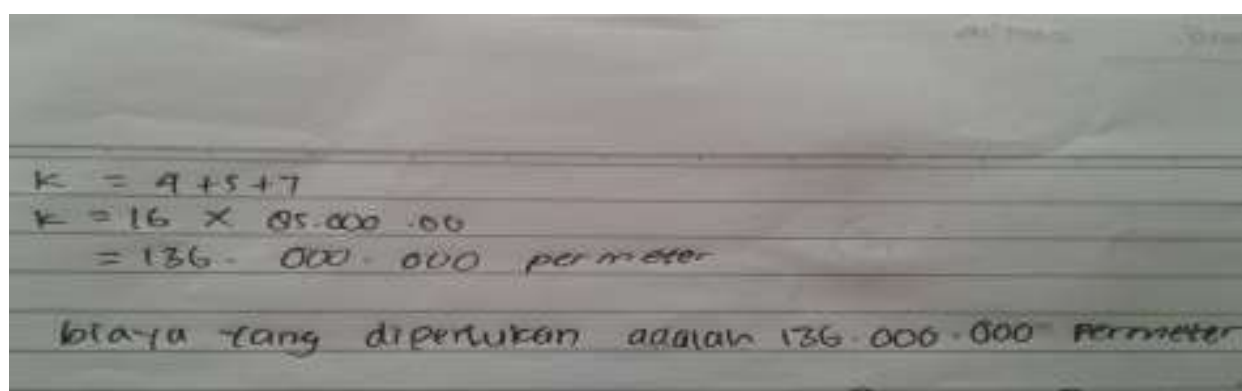

Figure 6. The description of question number 4 indicators provides arguments or reasons for answering and solving problems 
$S_{7}$ in this study are students who belong to the category high. Answers from students $S_{2}$ shown in question number 4 . This question is indicator 3, which provides arguments in solving the problem. $S_{7}$ does not provide arguments, formulates problems directly and is less precise in drawing conclusions. Then get a score of 2, even though the answer is correct because it doesn't provide an argument. $S_{7} S_{7} S_{7} S_{7} S_{7}$

\subsection{Evaluating Problem Solving}

The student's ability to evaluate the problem solving on this test resulted in an average percentage of $40 \%$. The percentage level of students' ability on this indicator is shown in the following table.

Table 8. Percentage of Level of Indicator Capability 4

\begin{tabular}{|l|l|l|}
\hline \multicolumn{1}{|c|}{$\begin{array}{c}\text { Level of Indicator } \\
\text { Capability }\end{array}$} & $\begin{array}{c}\text { The number } \\
\text { of students }\end{array}$ & $\begin{array}{c}\text { Percentage of Ability Level } \\
\text { Per Indicator }\end{array}$ \\
\hline Low & 9 & $45 \%$ \\
\hline Moderate & 5 & $25 \%$ \\
\hline High & 6 & $30 \%$ \\
\hline
\end{tabular}

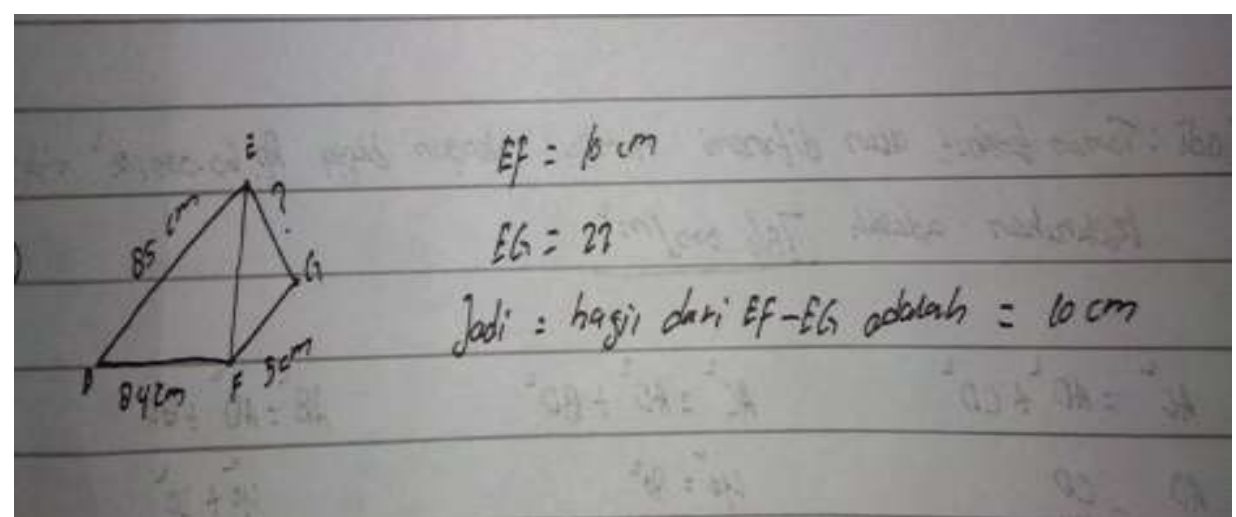

Figure 7. The description of question number 5 indicatorsevaluate the evidence or decisions that have been taken in solving the problem

$S_{5}$ in this study are students who belong to the category low. Answers from students $S_{5}$ shown in question number 5 , this problem is indicator 4 , which is evaluating the problem solving. Answer $S_{5}$ wrong, because it does not describe what you know in the problem and does not formulate the problem correctly, and cannot evaluate the problem. $S_{5}$

\section{Conclusion}

Based on the five test questions, it can be concluded that students can be categorized as highly skilled, in general students can determine the concept of the problem correctly, are able to formulate problems in solving problems, are able to provide reasons and arguments clearly, but students are less able to evaluate problems in solving problems. Students who are categorized as having moderate ability, students can determine the concept of the problem correctly, are able to formulate problems, but students are less clear in providing reasons and arguments clearly, and are less able to evaluate the problems contained in solving problems. Students who are categorized as low, students are able to determine the concept correctly, but students are less able to formulate problems, and students are unable to provide clear reasons.Graded Response Models (GRM). 


\section{References}

Arikunto, Suharsimi. 2009. Dasar-dasar Evaluasi Pendidikan (Edisi Revisi). Jakarta: Bumi Aksara.

Desmita. 2010. Psikologi Perkembangan Peserta Didik. Bandung: PT Remaja Rosdakarya. Ennis, R,H. 1996. Critical Thinking. New Jersey: Printice-Hall Inc

Glaser, E. and Paul, R,W. 2012. Critical Thinking, Membangun Pemikiran Logis. Jakarta: Pustaka Sinar Harapan.

Hendayawan, S, dkk. 2017. Analisis Kemampuan Berpikir kritis Matematis Tingkat Rendah pada Pembelajaran Berbasis Masalah dengan Greens Motivational Strategies. Aksioma. 8(2). 50-58.

Khodijah, Nyayu. 2006. Psikologi Belajar. Palembang: IAIN Raden Fatah PRESS.

Manfaat, B. dan Anasha, Z.Z. 2013. Analisis Kemampuan Berpikir Matematik Siswa dengan Menggunakan Graded Respons Models. Prosiding Seminar Nasional Matematika dan Pendidikan Matematika. Jurusan Pendidikan Matematika FMIPA UNY. 119-124.

Matteucci, M. and Stracqualursi, L. 2006. Estimation of Latent Trait Ability Using a Response Pattern of Graded Scores. Psychometric Monograph. 17.

Mirunnisa. 2019. Peningkatan Kemampuan Penalaran Matematis Siawa Sekolah Menengah Atas dengan Model Discovery Learning. Jurnal Numeracy. 6(1). 76-85.

Noer, Sri Hastuti. 2009. Peningkatan Kemampuan Berpikir Kritis Matematis Siswa SMP Melalui Pembelajaran Berbasis Masalah. Prosiding, Seminar Nasional Matematika dan Pendidikan Matematika FMIPA UNY.

Razi, Z. 2019. Penerapan Model Pembelajaran Kooperatif The Powerof Two untuk Meningkatkan Hasil Belajar Siswa. Jurnal Sains Riset. 8 (1). 31-36.

Razi, Z dan Mirunnisa. 2019. Model Discovery Learning Berbantuan Software Maple etrhadap Kemampuan Pemahaman Matematis. Jurnal Aksioma. 8(3). 520-527.

Sabandar, Joshua. 2008. Pembelajaran Matematika Sekolah dan Permasalahan Ketuntasan Belajar Matematika. Bandung: Universitas Pendidikan Indonesia.

Samejima, F. 1962. Estimation of Latent Ability Using a Response Pattern of Graded Scores, Research Bulletin. New Jersey: Educational Testing Service.

Sumarmo, Utari. 2010. Berpikir dan Disposisi Matematik: Apa, Mengapa, dan Bagaimana Dikembangkan Pada Peserta Didik. Makalah disampaikan pada seminar FBMIPA, Universitas Pendidikan Indonesia.

Surapranata. 2004. Analisis, Validitas, Reliabilitas dan Interpretasi Hasil Tes Implementasi Kurikulum 2004. Bandung: Remaja Rosdakarya.

Zohar, A., and Dori, Y.J. 2003. Higher Order Thinking Skills and Low Achieving Students: Are They Mutually Exclusive. The journal of the learning sciences, 12, 145-181. 